\title{
Snail blocks the cell cycle and confers resistance to cell death
}

\author{
Sonia Vega, ${ }^{1}$ Aixa V. Morales, ${ }^{1,3}$ Oscar H. Ocaña, ${ }^{1,3}$ Francisco Valdés, ${ }^{2}$ Isabel Fabregat, ${ }^{2}$ \\ and M. Angela Nieto ${ }^{1,4}$ \\ ${ }^{1}$ Instituto Cajal, Consejo Superior de Investigaciones Cieutificas, 28002 Madrid, Spain; ${ }^{2}$ Facultad de Farmacia, Universidad \\ Complutense, 28040 Madrid, Spain
}

The Snail zinc-finger transcription factors trigger epithelial-mesenchymal transitions (EMTs), endowing epithelial cells with migratory and invasive properties during both embryonic development and tumor progression. During EMT, Snail provokes the loss of epithelial markers, as well as changes in cell shape and the expression of mesenchymal markers. Here, we show that in addition to inducing dramatic phenotypic alterations, Snail attenuates the cell cycle and confers resistance to cell death induced by the withdrawal of survival factors and by pro-apoptotic signals. Hence, Snail favors changes in cell shape versus cell division, indicating that with respect to oncogenesis, although a deregulation/increase in proliferation is crucial for tumor formation and growth, this may not be so for tumor malignization. Finally, the resistance to cell death conferred by Snail provides a selective advantage to embryonic cells to migrate and colonize distant territories, and to malignant cells to separate from the primary tumor, invade, and form metastasis.

[Keywords: Snail; cell cycle; cell death; malignization; chick embryo; mouse embryo]

Received December 5, 2003; revised version accepted April 5, 2004.

The Snail family members Snail and Slug trigger epithelial-mesenchymal transitions (EMTs) during embryonic development and tumor progression (Nieto 2002). During development, they are involved in the ingression of the early mesodermal cells at gastrulation and in the delamination of the neural crest from the neural tube (Nieto 2002). Functional analyses in the chick (Nieto et al. 1994) and a striking interchange in the expression patterns at the sites of EMT in chicken and mouse embryos (Sefton et al. 1998) suggested that Slug induces the transition in the chick, whereas Snail triggers EMT in the mouse. Indeed, in mammalian cells Snail induces EMT and represses E-cadherin transcription (Batlle et al. 2000; Cano et al. 2000), and Snail mutant mice die at gastrulation due to a defective EMT and maintained Ecadherin expression (Carver et al. 2001). The analysis of the gene family in all major vertebrate groups indicated that Snail is higher in the gene hierarchy controlling neural crest development in fish, amphibians, and mammals (Locascio et al. 2002; Aybar et al. 2003).

Snail is also involved in the EMT that takes place concomitant with the acquisition of invasive properties in tumors (Nieto 2002; Thiery 2002). It is expressed in the invasive cells of tumors induced in the skin of mice (Cano et al. 2000) and in biopsies from patients with ductal breast carcinomas (Cheng et al. 2001; Blanco et al.

\footnotetext{
${ }^{3}$ These authors contributed equally to this work.

${ }^{4}$ Corresponding author.

E-MAIL anieto@cajal.csic.es; FAX 34-91-585-4754.

Article and publication are at http://www.genesdev.org/cgi/doi/10.1101/ $\operatorname{gad} .294104$.
}

2002), gastric cancer (Rosivatz et al. 2002), and hepatocellular carcinomas (Sugimachi et al. 2003). Snail appears as an early marker of the malignant phenotype and behaves as a prognostic factor (Blanco et al. 2002).

The process of EMT implies a dramatic phenotypic change that includes the loss of epithelial markers, the gain of mesenchymal markers, and changes in cell shape. Because Snail is able to induce a complete EMT (Batlle et al. 2000; Cano et al. 2000), it must have many targets. Indeed, together with E-cadherin, other direct targets for Snail repression that have been identified include the epithelial Mucin-1 (Guaita et al. 2002) and the components of the tight junctions claudins and occludin (Ikenouchi et al. 2003). Snail is upstream of molecules involved in the degradation of the basement membrane and extracellular matrix such as metalloproteinase 2 (MMP-2; Yokohama et al. 2003), the mesenchymal markers vimentin and fibronectin (Cano et al. 2000; Guaita et al. 2002), and other transcription factors such as ZEB-1 and LEF-1 (Guaita et al. 2002). Although a direct link between Snail expression and cytoskeletal proteins has not been reported, RhoB, a small GTPase involved in cytoskeletal actin rearrangements, lies downstream of Slug during chick neural crest delamination (Del Barrio and Nieto 2002).

By analyzing epithelial cells transfected with Snail and mouse and chick embryos, we show here that Snail also regulates cell-cycle progression and survival. Snail regulates components of the early to late G1 transition and the G1/S checkpoint, including the repression of Cyclin D2 transcription and the increase in $\mathrm{p} 21 / \mathrm{Cip} 1$. Concomi- 
tantly, Snail confers resistance to the lethal effects of serum depletion or TNF- $\alpha$ administration by activating the MAPK and PI3K survival pathways. These survival properties confer a selective advantage to the invasive and migratory cells during both embryonic development and tumor dissemination.

\section{Results}

\section{Snail impairs cell-cycle progression}

When stably expressed in different epithelial cell lines, both mouse and human Snail dramatically decreased cell growth, prompting us to analyze cell proliferation and cycle progression of such cells. When transfected with Snail (MDCK-Snail), MDCK cells underwent a complete EMT (Cano et al. 2000) and incorporated lower levels of BrdU after $24 \mathrm{~h}$ in culture $(25 \%$ of that observed in mock-transfected cells, Fig. 1A). Analysis by FACS (Fig. 1B) indicated that the vast majority of Snail-expressing cells $(93 \%)$ was in the G0/G1 phase of the cell cycle in basal conditions after $72 \mathrm{~h}$ in culture. However, these cells can respond to mitogens and proliferate, as observed $16 \mathrm{~h}$ after they were replated with $10 \%$ serum (Fig. 1B). The percentage of cells in G0/G1 was again much higher in MDCK-Snail transfectants $161 \%$ vs. $36 \%$ ) after $24 \mathrm{~h}$ in culture and at all other times analyzed (Fig. 1B). To check whether Snail-expressing cells had difficulties in progressing through the G1/S checkpoint, we analyzed the expression of the Cip/Kip proteins, essential to inhibit the activity of the cdk2-Cyclin E complex, and responsible for the hyperphosphorylation of the retinoblastoma protein $(\mathrm{Rb})$ and the subsequent progression from late G1 to the S phase (Ortega et al. 2002). Although the levels of p27 (Kip1) remained low in both MDCK-Mock and MDCK-Snail cells, Snail greatly increased the expression of p21 (Cip1) as shown in basal conditions and after $8 \mathrm{~h}$ (Fig. 2A) and $12 \mathrm{~h}$ in culture (Fig. 2B). Nevertheless, a decrease was observed after $16 \mathrm{~h}$, coincident with $\mathrm{Rb}$ hyperphosphorylation (Fig. 2A) and entry into $S$ phase (Fig. 1B). When we analyzed the levels of p21 at later times, we found that they increased again in Snail-expressing cells after $24 \mathrm{~h}$ and were always maintained at higher levels than in control transfectants (Fig. 2B). Thus, p21 expression is tightly regulated and maintained at a high level except for during short periods of time when cells are exposed to a high concentration of mitogens and respond by progressing through the cycle.

\section{Snail represses Cyclin D2 transcription}

The G1/S checkpoint requires the activity of Cyclin E and the activity of the Cyclins D helps to progress from early to late G1 passing the restriction point (R) where cells are committed to another round of division. Thus, we decided to analyze the expression of Cyclins D and E in the two cell lines. Although we could not detect significant differences in the amount of Cyclin E (data not shown) or Cyclin D3 (Fig. 3A) in MDCK Snail-expressing versus nonexpressing cells, we observed a decrease in the levels of Cyclins D1 and D2 (Fig. 3A). In addition, we also found that the expression of their partner, the cyclin-dependent kinase cdk4, was decreased in MDCKSnail cells (Fig. 3A). These results indicate that Snailexpressing cells, with limited amounts of Cyclins D, have an impairment to progress through the restriction point.

After we had observed that Snail-expressing cells contain low levels of Cyclins D, we wanted to assess whether they can be direct targets of Snail transcriptional repression. Although we found that the levels of Cyclin D1 mRNA were lower in cells expressing Snail compared to mock-transfected cells, those of Cyclin D2 were strongly down-regulated (Fig. 3B). Because the $C y$ clin D2 promoter contains two E-box consensuses for Snail binding (Mauhin et al. 1993) that are conserved among mouse, rat, and human (Bouchard et al. 1999), we analyzed the effect of Snail on Cyclin D2 transcription. We expressed mouse Snail cDNA together with reporter constructs of the human Cyclin D2 promoter in the keratinocyte cell line MCA3D, previously used to study the proximal E-cadherin promoter (Cano et al. 2000). Snail repressed the wild-type promoter activity of Cyclin $D 2$ to $\sim 55 \%$ of its activity (Fig. 3 C) but did not affect that
Figure 1. Snail expression impairs cell proliferation. (A) BrdU incorporation after a 1-h pulse in MDCK cells stably transfected with Snail (MDCKSnail) or the empty vector (MDCK-Mock). Brightfield images after $24 \mathrm{~h}$ in culture. (B) FACS analysis of the cell cycle in MDCK-Mock and MDCK-Snail cells after different times in culture.



B

\begin{tabular}{|c|c|c|c|c|}
\hline \multirow{2}{*}{\multicolumn{2}{|c|}{$\mathbf{D}$}} & \multicolumn{3}{|c|}{ Cell Cycle Phase } \\
\hline & & Go/G1 & $\mathbf{s}$ & G2-M \\
\hline \multirow{2}{*}{ isal } & MDCK-Mock & $55.7 \pm 1.8$ & $33.7 \pm 2.5$ & $10.6 \pm 0.8$ \\
\hline & MDCK-Snail & $92.6 \pm 0.8$ & $6.2 \pm 0.2$ & $1.2 \pm 0.7$ \\
\hline & MDCK-Mock & $62.1 \pm 0.8$ & $21.9 \pm 0.9$ & $16.0 \pm 0.8$ \\
\hline & MDCK-Snail & $95.0 \pm 0.4$ & $2.8 \pm 0.1$ & $2.2 \pm 0.3$ \\
\hline \multirow[t]{2}{*}{$6 \mathrm{~h}$} & MDCK-Mock & $28.3 \pm 0.5$ & $53.3 \pm 0.6$ & $18.4 \pm 0.8$ \\
\hline & MDCK-Snail & $39.5 \pm 0.3$ & $52.3 \pm 1.5$ & $7.8 \pm 1.3$ \\
\hline \multirow{2}{*}{ 4h } & MDCK-Mock & $36.2 \pm 0.2$ & $43.8 \pm 0.4$ & $20.0 \pm 0.4$ \\
\hline & MDCK-Snail & $66.3 \pm 1.1$ & $22.1 \pm 1.0$ & $11.6 \pm 0.3$ \\
\hline \multirow{2}{*}{$6 \mathrm{~h}$} & MDCK-Mock & $37.1 \pm 1.1$ & $48.5 \pm 1.1$ & $17.1 \pm 1.5$ \\
\hline & MDCK-Snail & $59.2 \pm 0.3$ & $30.3 \pm 0.6$ & $10.5 \pm 0.5$ \\
\hline \multirow{2}{*}{$18 \mathrm{~h}$} & MDCK-Mock & $36.9 \pm 0.8$ & $49.8 \pm 0.5$ & $13.3 \pm 0.5$ \\
\hline & MDCK-Snail & $64.0 \pm 0.8$ & $26.4 \pm 1.0$ & $9.7 \pm 0.6$ \\
\hline
\end{tabular}


A

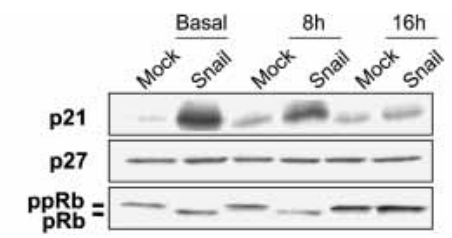

B

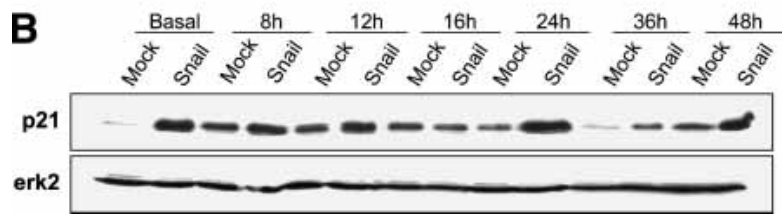

Figure 2. Snail alters the expression of proteins involved in progression from G1 to $S$ phase. Western blot analysis of MDCK-Mock and MDCK-Snail cells. (A) Levels of the G1 checkpoint molecules, the cdk inhibitors p21 and p27, and the degree of $\mathrm{Rb}$ phosphorylation. $(B)$ Levels of $\mathrm{p} 21$ after different times in culture. $\mathrm{Rb}$, retinoblastoma protein; $\mathrm{pRb}$, hypophosphorylated state; ppRb, hyperphosphorylated state. Representative experiments are shown $(n=4)$.

of promoter constructs carrying either a mutated or deleted distal E-box (located at -1600). Reporter activity was significantly decreased (to $\sim 40 \%$ ) when the proximal E-box (located at -1400) was mutated or deleted. As this construct is insensitive to Snail when the distal box is intact, both E-boxes are needed to mediate repression. The proximal box and sequences located immediately $3^{\prime}$ to it must be essential for promoter activity, because the -1303 D2-Luc deletion provoked a 10-fold decrease in activity (Fig. 3C). Similar results were obtained when human Snail cDNA constructs were used (data not shown). Thus, Snail can repress the activity of the Cyclin D2 promoter in epithelial cells. The presence of the proximal E-box $(-1400)$ is needed for the distal box $(-1600)$ to repress, and the region between -1400 and -1300 that includes the proximal box acts as an enhancer.

\section{Snail and the cell cycle in the mouse embryo}

Having seen that Snail repressed Cyclin D2 expression in cultured cells, we set out to determine whether the same could occur during embryonic development. Thus, we compared the expression of Cyclins D1 and D2 with that of Snail in 8.5-d postcoitum (dpc) mouse embryos (Fig. 4). At this developmental stage, Snail is expressed in regions undergoing EMT such as the premigratory neural crest and the primitive streak (Nieto et al. 1992; Smith et al. 1992; Sefton et al. 1998), and in mesodermal derivatives including the decondensing somites and the allantois (Fig. 4A,D,G,J). Cyclin D2 transcripts were readily detected at high levels in the neural plate (Fig. 4F) and the neural tube (Fig. 4I), whereas they were absent from Snail-expressing regions (Fig. 4F,I,L), evidencing a clear inverse correlation in their expression patterns. Cyclin $D 1$ was also expressed in the neural tube (Fig. 4E,H) and absent from regions expressing high levels of Snail tran- scripts such as the allantois (Fig. 4K). However, Cyclin D1 transcripts were observed in regions where Snail was only moderately expressed, including the decondensing somites (Fig. 4H). Thus, our data are compatible with Snail being a strong repressor of Cyclin D2 transcription, and are in agreement with the results obtained from Northern analysis of both Cyclin D1 and D2 and with those of the Cyclin D2 promoter activity in epithelial cells.

The impairment in cell-cycle progression in Snail-expressing cells was due not only to the maintained downregulation of Cyclin D2 transcription but also to the changes in the expression of additional components of the G1/S checkpoint. Indeed, the expression of Snail was correlated with an increase of the proportion of cells in G0/G1 (Fig. 1). To assess whether a similar change occurred in vivo, we compared the pattern of Snail expression with that of BrdU incorporation in mouse embryos to visualize cells in the $S$ phase of the cycle (Fig. 5A,B). In agreement with the data from cell cultures, in the regions of the embryo where Snail was expressed, a much lower proportion of nuclei accumulated BrdU. In general, it was possible to discern a complementary pattern of Snail expression and BrdU incorporation within the em-



Figure 3. Snail represses Cyclin D2 transcription. (A) Analysis of $\mathrm{D}$ cyclins and their partner cdk4. Immunoblotting of total erk2 was used as a control of gel loading. (B) Analysis of Cyclins $D 1$ and $D 2$ transcription by Northern blot of RNA extracted from MDCK-Mock and MDCK-Snail cells after different times in culture. The GAPDH probe was used as a control of loading. (C) Activity of the Cyclin D2 promoter. Luciferase reporter constructs carrying the wild-type human Cyclin D2 promoter $(-1624)$ or independent deletions/mutations in the two E-boxes were transfected into MCA3D cells together with a mouse Snail expression vector or the empty vector (pcDNA3) as a control. Luciferase activity was assayed $40 \mathrm{~h}$ after transfection. Activity is expressed relative to that of the wild-type construct. Results are the mean values \pm S.E. of duplicates from four independent experiments. 
Figure 4. An inverse correlation exists between Cyclin D2 and Snail expression in mouse embryos. Wholemount in situ hybridization of 8.5 -dpc mouse embryos $(A-C)$ and transverse paraffin sections of the same embryos taken at the level of the posterior hindbrain $(D-F)$, the trunk $(G-I)$, and the allantois $(J-L)$. Snail expression can be observed at the edges of the neural plate $(D, \mathrm{pnc})$ corresponding to premigratory crest cells undergoing EMT. Snail expression is maintained in crest cells after delamination $(G, \mathrm{nc})$, and it is also apparent in the decondensing somites $(G, \mathrm{~s})$ and in the allantois $(J, \mathrm{al})$. An inverse correlation between Snail and Cyclin D2 transcripts is readily observed in all the tissues analyzed (cf. $D, G, J$ and $F, I, L) .(K)$ Although this correlation is not so striking for Snail and Cyclin D1, note that Cyclin D1 expression is not detected in regions with high levels of Snail transcripts such as the allantois. (al) Allantois; (hb) hindbrain; (nc) neural crest; (np) neural plate; (nt) neural tube; (pnc) premigratory neural crest; (s) somite.

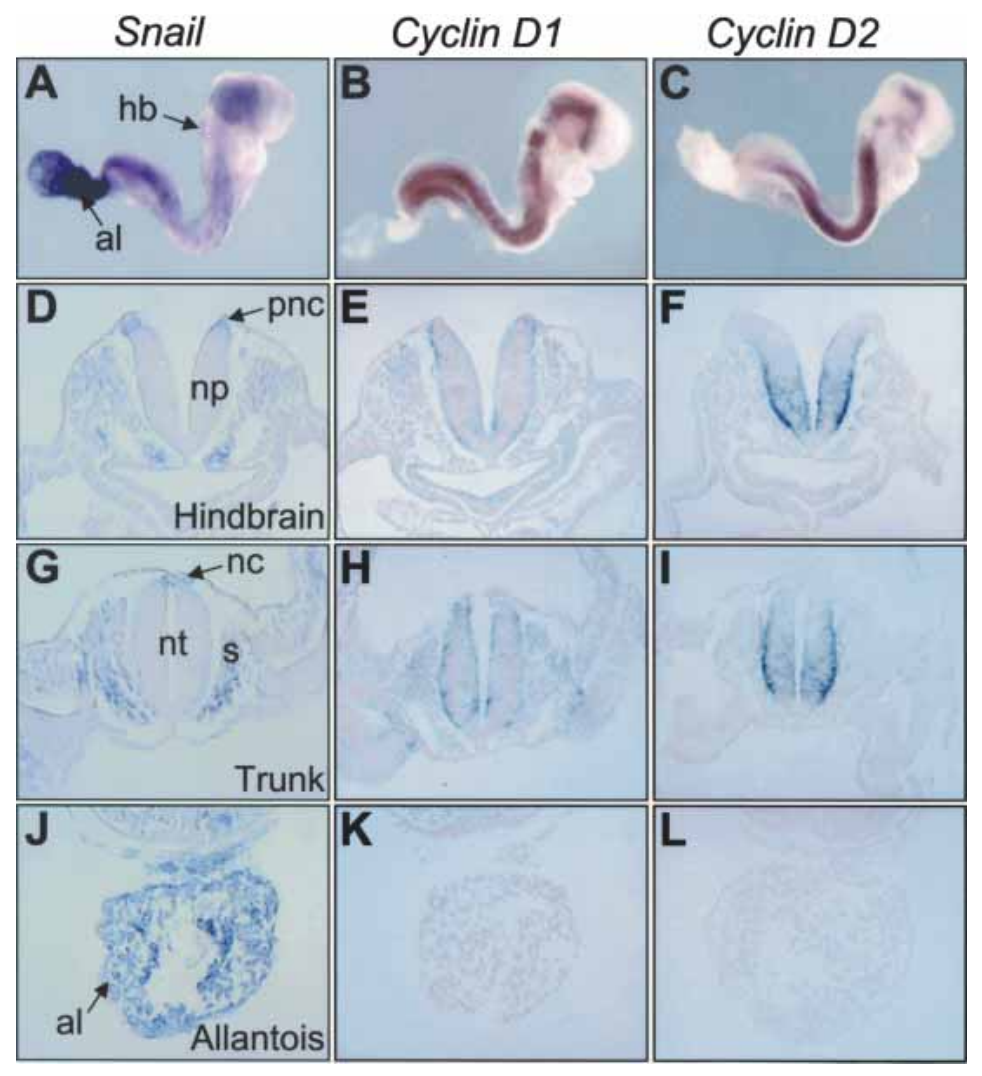

bryo (Fig. 5A,B). On the whole, as BrdU incorporation increased, Snail expression decreased (Fig. 5, cf. A and B [along the proximodistal axis of the allantois], C and D [in the section taken through the forebrain]). We also analyzed the phosphorylation of histone $\mathrm{H} 3$ to quantify the cells undergoing mitosis (Prigent and Dimitrov 2003) in the developing nervous system of 8.5 -dpc mouse embryos. We observed high levels of phospho-H3 in the ventricular surface of the neural epithelium, where nuclei undergo mitosis (Fig. 5G,H). When quantified, at both the head and trunk levels, an approximately fivefold decrease in labeling was observed in the Snail-expressing regions compared to similar-sized regions located in the intermediate or ventral areas. These results indicate that Snail-expressing cells are difficult to find undergoing DNA synthesis or mitosis both in culture and in embryos.

\section{Snail confers resistance}

to serum depletion-induced cell death

In several studies of hepatocytes (Valdés et al. 2002) and cancer cells progressing towards malignancy (Thiery 2002; Siegel and Massagué 2003), the transition to the mesenchymal phenotype is associated with a reduced susceptibility to apoptosis. Because Snail induces a complete EMT in MDCK cells (Batlle et al. 2000; Cano et al. 2000), accompanies tumor malignancy (Blanco et al. 2002; Sugimachi et al. 2003), and is induced in hepatocytes undergoing EMT (Spagnoli et al. 2000; Valdés et al.
2002), we tested whether Snail conferred resistance to cell death. Two main pathways can provoke apoptosis, the stress pathway triggered by developmental cues or intracellular damage ( $\gamma$-irradiation, cytokine deprivation, etc.), and the activation of death receptors such as those of the TNF family mediated by extracellular signals, among them TNF- $\alpha$, Fas ligand, and Trail.

To analyze the response to cellular stress, cells were maintained in the absence of serum. MDCK-Snail cells survived for at least $7 \mathrm{~d}$, whereas a large amount of cell death was seen in mock-transfected cells after 2-3 d of serum deprivation (Fig. 6A). After $48 \mathrm{~h}$ in culture, labeling with propidium iodide showed that whereas mock transfectants had $10.3 \pm 0.1 \%$ positive nuclei, only $3.8 \pm 0.2 \%$ of the nuclei of Snail-expressing cells were labeled. Caspase- 3 is involved in the cell death response and was three times more active in mock-transfected cells than in the corresponding Snail-expressing cells (Fig. 6B).

To check whether Snail may confer resistance to the death induced by developmental cues, we compared the pattern of cell death with that of Snail expression in mouse embryos (Fig. 6C). Although a clear pattern of cell death has been identified in rhombomeres (r) 2, 3, and 5 in the developing hindbrain of the chick (Graham et al. 1996; Ellies et al. 2000), the situation is not so clear in the mouse (Trainor et al. 2002). By comparing with the known expression of Krox-20 in the presumptive rhombomeres (pr) 3 and 5 at this developmental stage (Fig. $6 \mathrm{C})$, we observed numerous dying cells in pr2, 3, 5, and 6 


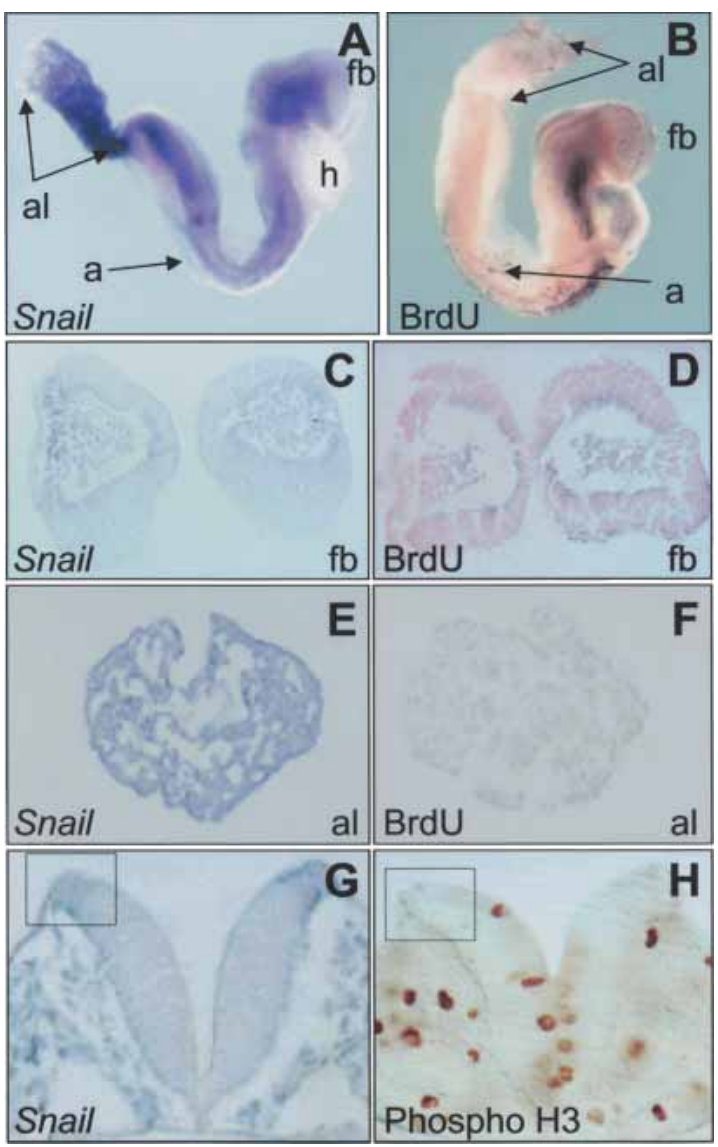

Figure 5. An inverse correlation exists between proliferation and Snail expression in mouse embryos. The embryos in $A$ and $B$ show a side-by-side comparison between Snail expression and BrdU incorporation as a measure of cell proliferation in the whole embryo in culture. An overall complementary pattern is observed, that can be better examined in the sections taken at the level of the forebrain $(C, D)$ and the base of the allantois $(E, F)$. $G$ and $H$ show sections at the trunk level to compare Snail expression with histone $\mathrm{H} 3$ phosphorylation, taken as a measure of cells undergoing mitosis. The squares mark the Snailexpressing region of the neural epithelium. (a) Amnion; (al) allantois; (fb) forebrain; (h) heart; (hb) hindbrain.

(NBS; Fig. 6C). Conversely, pr4 and the anterior spinal cord are regions where cell death was not apparent, coinciding with areas of Snail expression (Fig. 6C, high magnification). The absence of Snail expression from other regions of intense cell death was also apparent in the midbrain and forebrain, and in other tissues outside of the central nervous system such as the developing heart (Fig. 6C). In contrast, mesenchymal tissues of the head, including the migratory neural crest cells, showed high levels of Snail transcripts and no cell death. In summary, an inverse correlation between cell death and Snail expression existed in the embryos analyzed (Fig. 6C).

Given that Snail-expressing cells were resistant to serum depletion, we studied the activity of different survival pathways in these cells. Both the MAPK and PI3K pathways are highly active in Snail-expressing cells (Fig.
7A,B). In agreement with the higher levels of PI3K activity, we also found a much greater phosphorylation of its downstream effector Akt (Fig. 7B). Both the MEK/Erk and PI3-K/Akt pathways can mediate the up-regulation of Bcl- $\mathrm{x}_{\mathrm{L}}$ expression (Ramljak et al. 2003), a death-inhibitory member of the Bcl-2 family that blocks the stressinduced release of cytochrome $\mathrm{c}$ from the mitochondria. Thus, we looked at the expression of Bcl- $\mathrm{x}_{\mathrm{L}}$ in MDCKSnail cells and found that it was increased at all times analyzed (Fig. 7C). These data indicate that the activation of the MEK/Erk and PI3-K/Akt pathways may explain the survival properties associated with Snail expression following serum depletion.

\section{Snail protects from TNF- $\alpha$-induced cell death}

Because Snail expression conferred resistance to stressinduced cell death, we checked whether Snail-expressing cells might also be resistant to that induced by proapoptotic signals that activate the death receptor pathway such as TNF- $\alpha$. Indeed, whereas mock-transfected MDCK cells died within $24 \mathrm{~h}$ of treatment, MDCK-Snail cells survived (Fig. 8A). Caspase-8 is specifically recruited to the death receptors upon ligand binding and is then auto-activated initiating the apoptotic pathway. Accordingly, we found that treatment with TNF- $\alpha$ induced the activation of caspase- 8 in mock-transfected cells. An approximately fivefold decrease in the activity of caspase-8 was observed in Snail-expressing cells after $24 \mathrm{~h}$ of treatment compared with that of mock transfectants. This result substantiates that the death observed in MDCK cells was mediated by the activation of this pathway (Fig. 8B). As expected, in both cell types the activity of the initiator, caspase-8, correlated with that of the effector, caspase-3 (Fig. 8C), confirming that the expression of Snail protects the MDCK cells from TNF- $\alpha$ induced death.

\section{Slug behaves in the chick as Snail in the mouse}

We showed previously that the Snail family member Slug induces EMT in the chick embryo (Nieto et al. 1994) and that in general, the expression patterns of these two family members are interchanged at the sites of EMT in birds and mammals (Sefton et al. 1998). Indeed, the cells undergoing EMT in the neural tube and the primitive streak express Snail in the mouse and Slug in the chick. Nevertheless, Snail can induce EMT when ectopically expressed in the chick embryo hindbrain (Del Barrio and Nieto 2002), indicating that the two proteins can be functionally equivalent during embryonic development. However, even though they can be functionally equivalent, only one gene is expressed in each corresponding embryo and thus, Snail could not play a role in the control of cell division or survival in the neural tube of the chick, because it is not expressed there. Thus, this functional equivalence and the striking interchange in the expression patterns led us to analyze whether the family member expressed in the chick, Slug, can regulate cell-cycle progression and survival in the neural tube. 
Vega et al.

Figure 6. Snail confers resistance to apoptosis induced by serum deprivation. (A) Cell viability was assessed by propidium iodide staining $48 \mathrm{~h}$ after serum depletion. $(B)$ Caspase-3 activity at different times after serum removal represented as mean values \pm S.E. from three independent experiments carried out with duplicate dishes. Note the low levels of activity in Snail-expressing cells $48 \mathrm{~h}$ after serum deprivation compared to the mock-transfected cells. $(C)$ Cell death visualized using Nile Blue Sulphate staining is compared side-by-side with Snail expression in the head of an 8.5-dpc mouse embryo. The pattern of cell death assessed by Nile Blue Sulphate (NBS) staining (stars) is complementary to that of Snail (brackets). A similar embryo hybridized with Krox-20 to indicate the relative position of pre-rhombomeres (pr) 3 and 5 in the hindbrain to help compare the pattern of cell death and Snail expression. The inverse correlation can be better assessed in the high-power photographs. (fb) Forebrain; (h) heart; (mb) midbrain; (sc) anterior spinal cord.
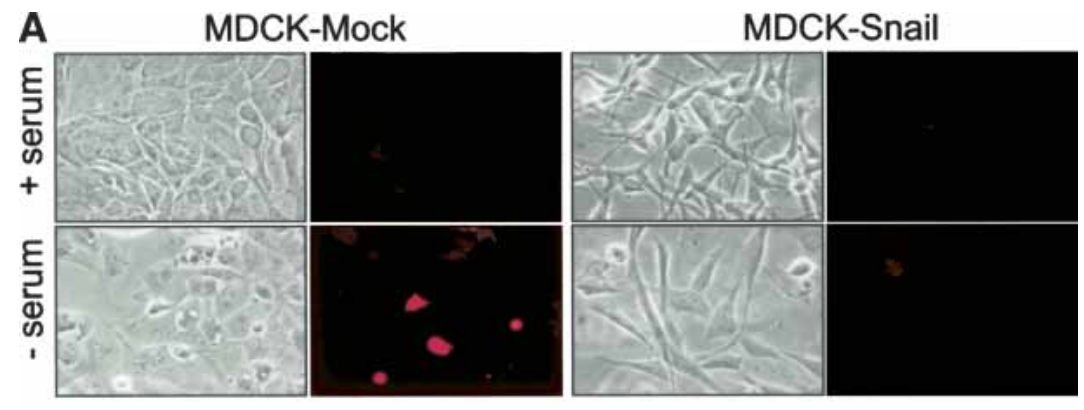

\section{B}
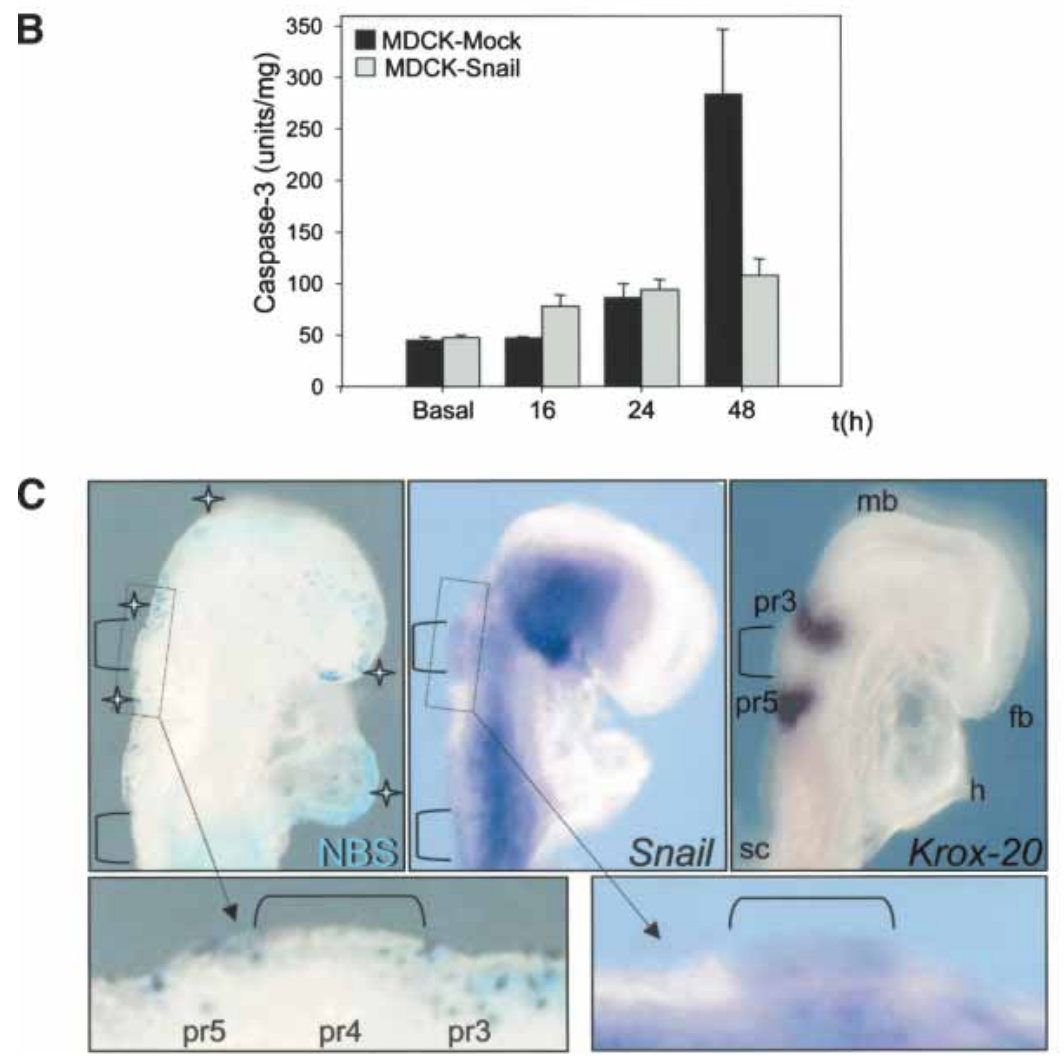

To analyze the cell cycle we measured both BrdU incorporation and phospho-H3 expression in chick embryos as we had performed for the mouse. We observed high levels of cell proliferation in the basal half of the neural tube epithelium, where the nuclei undergo DNA synthesis. In contrast, and as previously described (Burstyn-Cohen and Kalcheim 2002), the levels of incorporation were much lower in the dorsal region of the neural tube at the level of the epithelial somites (Fig. 9A). Interestingly, the dorsal neural tube is occupied by the premigratory neural crest, which expresses high levels of Slug transcripts (Fig. 9B). Quantification of BrdUpositive cells indicated that the proportion of cells in the $S$ phase of the cycle was approximately three times less in the Slug-expressing area compared to that found in nonexpressing regions of a similar size (data not shown). When we quantified the cells containing phosho-H3 all along the dorsoventral axis of the neural tube, we found that in the Slug-expressing area, positive cells were only $\sim 15 \%$ of those found in adjacent regions (data not shown). Thus, with respect to the cell cycle, Slug-expressing cells in the developing neural tube of the chick embryo behave as Snail-expressing cells in the mouse embryo and similarly, they are difficult to find undergoing DNA synthesis or mitosis.

As already mentioned, cell death has been analyzed in detail in the chick embryonic hindbrain (Ellies et al. 2000), with cell death in neural crest cells from r3 and r5 being crucial for the patterning of the branchial region (Graham et al. 1996; Ellies et al. 2002; Trainor et al. 2002). We carried out a careful analysis of cell death by both TUNEL and NBS staining and compared the data with the expression of Slug. We found that $\mathrm{r} 4$, which is naturally protected from cell death, expressed much higher levels of Slug transcripts than the adjacent rhombomeres (Fig. 9C-E). This result is reminiscent of the data regarding cell death and Snail expression from mouse embryos (see Fig. 6C). 
Taking advantage of the amenability of the chick embryo to experimental manipulation, we further studied the role of Slug in promoting cell survival by overexpressing it in the neural tube in ovo. High levels of GFP (and Slug, data not shown) expression could be achieved by co-electroporation of Slug- and GFP-encoding vectors into the right-hand side of the developing neural tube (Fig. 9F). Several streams of electroporated neural crest cells were observed migrating from the hindbrain (Fig. 9F). NBS staining of the same embryo shows that the area of Slug overexpression presents a dramatic reduction of the naturally occurring cell death (Fig. 9G,H). Rescue of cell death could be observed in $53 \%$ of the electroporated embryos $(n=30)$, indicating that Slug can act as a survival factor in the chick embryo hindbrain. Is it worth noting here that the amount of naturally occurring cell death in the different rhombomeres correlates with the balance in the expression of the death inducer BMP (Graham et al. 1994) and the survival factor Slug. Indeed, r4 expresses high levels of Slug and very low levels of BMP4. This balance also explains why in our overexpression experiments the death of $\mathrm{r} 2$ cells /with low levels of both BMP4 and Slug) can be more effectively rescued by Slug overexpression than that of $\mathrm{r} 5$ (which expresses very high levels of BMP4; data not shown).

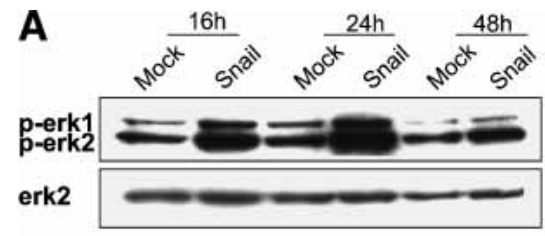

B
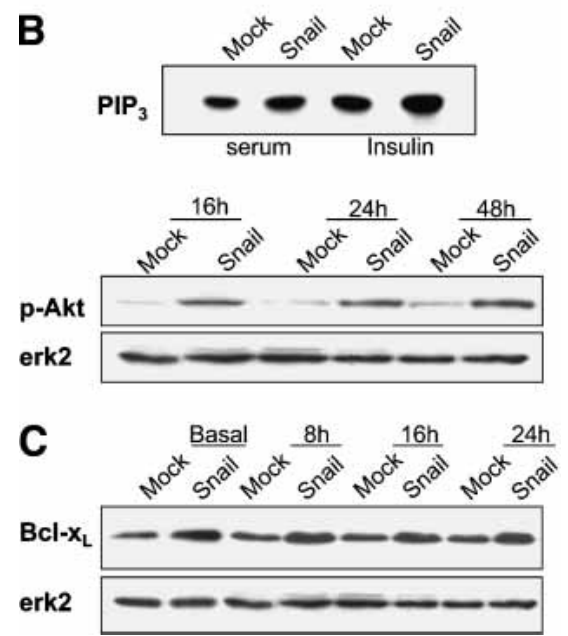

Figure 7. Snail activates survival pathways. Molecules from different survival pathways were analyzed in cells cultured in the absence of serum and collected at different times. The levels of active ERKs (phospho-erk1 and phospho-erk2; $A$ ), active Akt $(B)$, and Bcl- $\mathrm{x}_{\mathrm{L}}(C)$ were analyzed by Western blot and found to be increased in Snail-expressing cells. Total erk2 was used as a control for gel loading. (B) Higher levels of PI3K activity were also detected in Snail-expressing cells as analyzed by thin-layer chromatography, compatible with the higher levels of phosphorylation found for Akt.
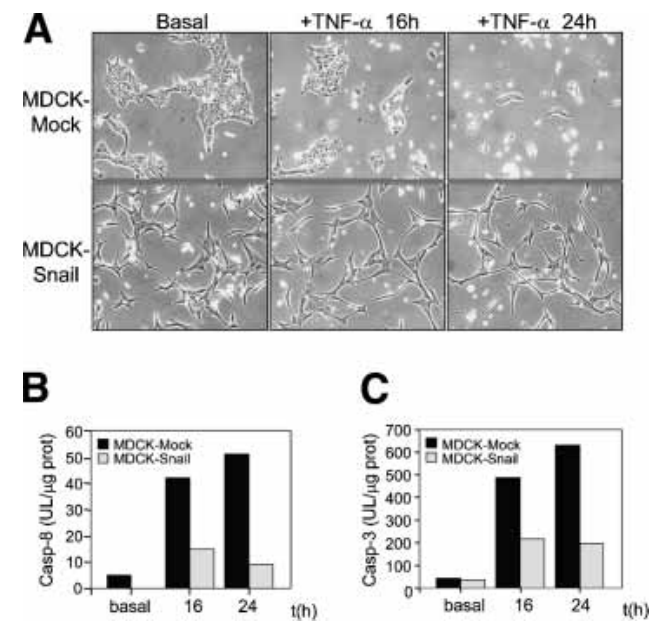

Figure 8. Snail confers resistance to the cell death induced by TNF- $\alpha$. Mock and MDCK-Snail-expressing cells were treated with TNF- $\alpha(5 \mathrm{ng} / \mathrm{mL})$ after being pretreated with cycloheximide $(0.5 \mu \mathrm{g} / \mathrm{mL}$ for $30 \mathrm{~min})$ to prevent the induction of the survival protein NFкB. (A) Photographs of the cultures taken after 16 or $24 \mathrm{~h}$ of treatment. $(B, C)$ The activity of the death receptors-specific caspase- 8 and effector caspase-3, respectively, are shown from one representative experiment. Note the low activity of both caspases in Snail-expressing cells, explaining the healthy appearance observed in $A$.

Although some of the migratory Slug-expressing cells pass close to the otic vesicles, the dying cells indicated by black stars in Figure $9 \mathrm{H}$ are nonelectroporated ectodermal cells (as assessed in sections, data not shown). These results highlight the specificity of this rescue in the electroporated cells, and confirm that Slug confers resistance to cell death in the developing embryo.

\section{Discussion}

Snail genes impair cell-cycle progression in cultured cells and in developing embryos

The epithelial mesenchymal transition (EMT) confers migratory and invasive properties to epithelial cells, critical for the generation of cells that originate at a distance from their final destination (Nieto 2002) during embryonic development. When the transition to a mesenchymal phenotype occurs in the adult, it is usually associated with pathological processes such as tumor progression (Thiery 2002). Concomitant with the acquisition of motility, cells undergo dramatic changes in cell adhesion properties and cell shape. Snail induces a complete EMT in epithelial cells concurrent with the aforementioned changes (Batlle et al. 2000; Cano et al. 2000) and is associated with the process of EMT in both physiological and pathological conditions (Nieto 2002; Thiery 2002; Yáñez-Mo et al. 2003). The conversion to mesenchyme implies a profound reorganization of the cytoskeleton that may be incompatible with a highly proliferative estate. Here we demonstrate that cell proliferation is impaired in Snail-expressing cells, supporting this 


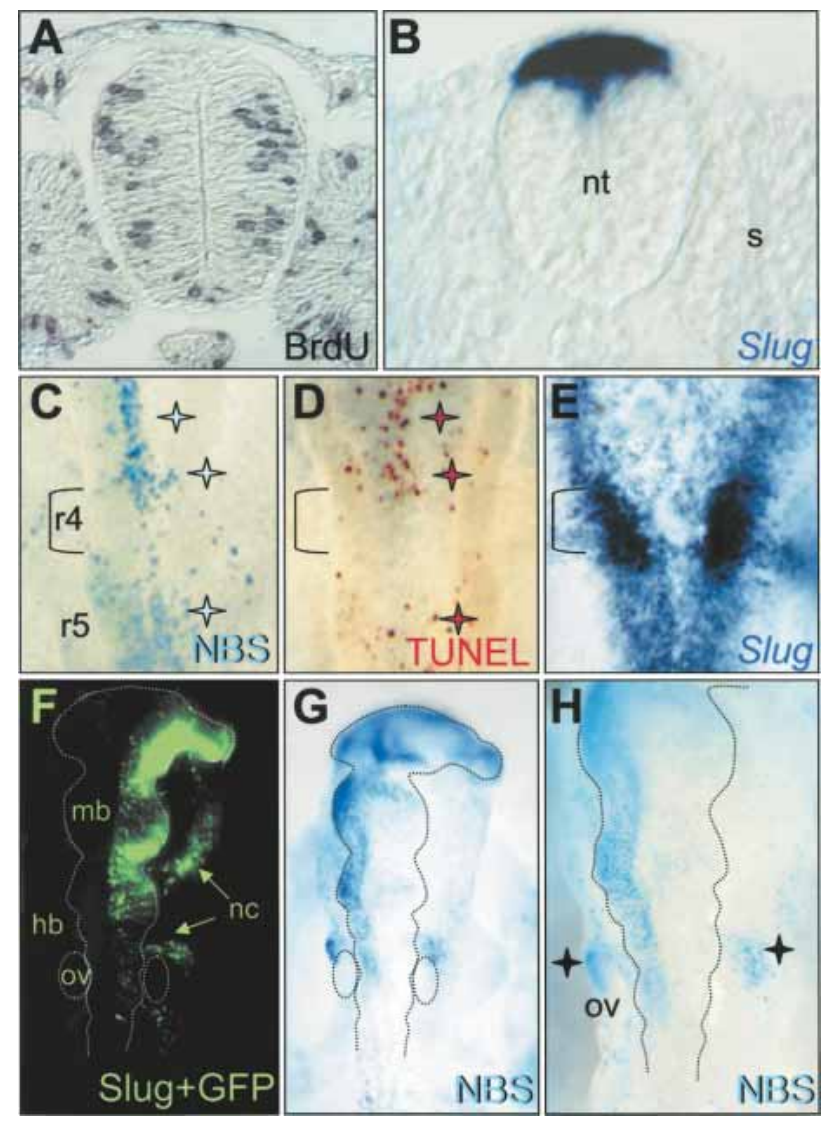

Figure 9. Slug expression correlates with little proliferation and protects the developing neural tube from physiological cell death in the chick. (A) In ovo BrdU incorporation was analyzed in transverse sections. One such section from the trunk of a stage 11 chicken embryo is shown. (B) A similar section hybridized with a Slug probe. Note the absence of BrdU in the premigratory neural crest, showing high levels of Slug expression. $(C, D)$ The pattern of cell death in the hindbrain region of a stage 12 chick embryo as assessed by NBS and TUNEL staining, respectively. Compare the pattern of cell death (blue and brown stars in $C, D$ ) with that of Slug transcripts $(E)$. As previously described, $\mathrm{r} 4$ shows very few apoptotic cells, coinciding with high levels of Slug transcripts (brackets). $(F-H)$ An embryo electroporated with plasmids containing chick Slug and GFP cDNAs at stage 8 and analyzed $15 \mathrm{~h}$ later (stage 12). (F) GFP (and thus, Slug) expression is observed in the right-hand side of the neural tube and in cells migrating from it. $(G)$ NBS staining of the same embryo shows a striking decrease in cell death in the side where Slug is overexpressed. $(H)$ A higher-magnification picture that allows a better assessment of the region protected from cell death. The dotted lines demarcate the borders of the neural tube and the otic vesicle. The black stars indicate a region of ectodermal cell death that appears symmetrical on both sides of the embryo (see text). (hb) Hindbrain; (mb) midbrain; (nc) neural crest; (nt) neural tube; (ov) otic vesicle, (s) somite.

hypothesis. Further evidence that profound morphological changes are incompatible with high proliferation can be seen in the low BrdU incorporation in the premigratory neural crest (Burstyn-Cohen and Kalcheim 2002; the present study), in the mitotic arrest in the cells of the ventral furrow during Drosophila gastrulation (Foe
1989|, the low proliferation in the invasive front of carcinomas (Jung et al. 2001), and the link between high p21 expression and poor prognosis in breast carcinomas (Yang et al. 2003). Significantly, Snail is expressed and triggers EMT in all of these territories and circumstances (for review, see Nieto 2002).

We have found that Snail impairs the transition from early to late G1 by maintaining low levels of Cyclins D and can block the G1/S transition by maintaining high levels of p21. However, Snail-expressing cells can respond to mitogenic signals by transiently decreasing $\mathrm{p} 21$ expression, which favors the transition to the $\mathrm{S}$ phase. Interestingly, neural crest cells synchronously enter into the $S$ phase upon delamination from the neural tube (Burstyn-Cohen and Kalcheim 2002), which occurs after the process of EMT has been completed. Thus, when Snail (and Slug in the chick) induces EMT in the premigratory neural crest cells, it probably blocks proliferation, synchronizing them in G1 and allowing morphological changes to occur. Subsequently, cells will enter S phase upon delamination. Interestingly, the bladder epithelial carcinoma cell line NBT-2 is receptive only to FGF-induced EMT at G1 (Bonneton et al. 1999), and lymphocyte migration and hepatoma cell invasion occur only in G1 (Ratner 1992; Iwasaki et al. 1995). Thus, although a deregulation/increase in cell division is crucial for tumor formation and growth, this is not so for tumor malignization. The behavior of invasive cells allows tumor proliferation to be dissociated from malignancy.

\section{Snail genes protect cultured cells and embryos from cell death induced by both the retrieval of survival factors and apoptotic signals}

Selective cell death is of crucial importance for sculpting the embryo and maintaining tissue homeostasis. However, deregulation of programmed cell death can be critical in pathological processes such as cancer. Several studies have correlated the conversion to a mesenchymal phenotype with cell survival. Indeed, EMT protects fetal hepatocytes from the death induced by TGF- $\beta$ (Valdés et al. 2002). Interestingly, TGF- $\beta$ has multiple effects on cellular behavior, from inducing growth arrest and death to triggering EMT, survival, and tumor progression (Siegel and Massagué 2003). Indeed, when expressed in the skin of mice, TGF- $\beta$ inhibits the formation of benign tumors but increases the frequency of invasive spindle carcinomas (Cui et al. 1996). Members of the TGF- $\beta$ superfamily including TGF- $\beta$ s and BMPs induce Snail/Slug expression in several systems such as hepatocytes (Spagnoli et al. 2000; Gotzmann et al. 2002; Valdés et al. 2002), epithelial and mesothelial cells (Peinado et al. 2003; Yáñez-Mo et al. 2003), and in the developing embryo (Dickinson et al. 1995; Liem et al. 1995; Romano and Runyan 2000; Piedra and Ros 2002). When Snail genes are induced by TGF- $\beta$, EMT is triggered and cells become resistant to TGF- $\beta$-induced cell death (Valdés et al. 2002), consistent with Snail activating the Mek/Erk and PI3K/Akt survival pathways. TGF- $\beta$ is also capable of inducing the progression towards invasive car- 
cinoma (Cui et al. 1996; Siegel and Massagué 2003), and this is usually explained by the tumor cells overcoming the TGF $\beta$-induced growth arrest (Siegel and Massagué 2003). However, in light of our data, it seems more likely that these invasive tumor cells overcome cell death and not growth arrest. Indeed, TGF- $\beta$ induces EMT in epithelial cells and hepatocytes concomitant with the inhibition of apoptosis but without altering the growth retardation effect (Lehmann et al. 2000; Valdés et al. 2002; Peinado et al. 2003).

With respect to embryonic development, we show here that the expression of Snail genes in the chick and the mouse are inversely correlated with cell death in different developing tissues. Significantly, Slug overexpression protects the neural crest from the naturally occurring cell death in the chick hindbrain. Interestingly, members of the BMP family induce Snail or Slug expression in the hindbrain (Nieto 2002), and BMPs are also responsible for the cell death induced in particular rhombomeres (Graham et al. 1996). This situation appears to be similar to the response of hepatocytes to TGF- $\beta$, where this factor induces cell death in half of the cell population and induces EMT and resistance to TGF- $\beta$ induced cell death in the other half (Valdés et al. 2002). TGF- $\beta$-induced EMT and survival in both hepatocytes and epithelial cells occurs concomitantly with Snail induction (Valdés et al. 2002; Peinado et al. 2003). Altogether, these data are in agreement with the notion that high levels of Snail/Slug expression in both mouse and chick hindbrains are sufficient to overcome the BMPinduced cell death.

Other members of the Snail superfamily are thought to mediate cell survival. In Caenorhabditis elegans, Ces-2 represses the Scratch homolog Ces-1 (Metzstein and Horwitz 1999), promoting the physiological death of a particular class of neurons. In humans, a translocation converts the Ces-2 homolog (HLF) in an activator that in turn induces Slug expression, leading to aberrant cell survival and leukemogenesis (Inukai et al. 1999). Furthermore, hematopoietic progenitors in Slug null mutant mice show an increased sensitivity to the death induced by $\gamma$-irradiation (Inoue et al. 2002; Pérez-Losada et al. 2003). However, there is no indication that Scratch protects cells in C. elegans physiology (Metzstein and Horwitz 1999; Thellmann et al. 2003), or that Slug promotes survival in physiological circumstances in mammals. The evidence in these cases points to an anti-apoptotic function following DNA damage (Inoue et al. 2002; Pérez-Losada et al. 2003). It thus seems likely that Snail in mammals and Slug in avians may be more efficient in conferring resistance to cell death, with the other family member maintaining certain activity of this ancestrally inherited property. The ancestral condition associated with the Snail superfamily is also supported by the fact that Scratch is the member acting as such in C. elegans, as the nematode does not seem to express any functional Snail protein (Manzanares et al. 2001).

In conclusion, Snail favors changes in cell shape rather than proliferation in cells that become migratory, in accordance with the often neglected low rates of prolifera- tion observed at the invasive front of tumors. Concomitantly, Snail offers protection from both stress-induced cell death and that provoked by pro-apoptotic signals. In this way, Snail confers a selective advantage to invasive cells to migrate through hostile territories. This resistance to cell death is essential in the embryo for migratory cells to reach their final destinations and in the adult for malignant cells to disseminate and form metastasis.

\section{Materials and methods}

\section{Cell lines and antibodies}

Canine MDCK (Madin-Darby canine kidney) and mouse epidermal keratinocyte MCA3D cells were grown in Dulbecco's modified Eagle medium (DMEM) and Ham's F12, respectively, supplemented with $10 \%$ fetal calf serum (FCS). The following antibodies were used: Polyclonal antisera against Cyclins D1, D2, and D3, cdk4, p21, p27, Erk2, and Bcl-x (Santa Cruz Biotechnology), anti-phospho Akt (New England Biolabs), and Phosphohistone-3 (Upstate Biotechnology); monoclonal p21/ Cip1 and retinoblastoma protein (Pharmingen BD Biosciences) and anti-MAPK (p44/p42; Cell Signaling Technology) antibodies. As secondary antibodies, both peroxidase-conjugated (antimouse and anti-rabbit) were used (Bio-Rad Laboratories) together with a biotinylated anti-rabbit serum (Vector).

\section{Embryos}

Mouse embryos were obtained from natural matings of Balb-C mice from the animal facility at the Cajal Institute. Fertilized hen eggs were obtained from Granja Santa Isabel, Córdoba, Spain. The age of mouse embryos was determined as days postcoitum (dpc), the day on which the vaginal plug was detected being designated $0.5 \mathrm{dpc}$. Eggs were incubated and opened, and the embryos staged according to Hamburger and Hamilton (1951).

\section{Analysis of cell proliferation through BrdU incorporation and phosphohistone-3 immunohistochemistry}

To measure the percentage that incorporated 5-bromo-2'-deoxyuridine (BrdU), cells were grown on coverslips in DMEM plus $10 \%$ FCS. BrdU (10 $\mu \mathrm{M}$ in PBS) was added at different times, and cells were fixed and stained $1 \mathrm{~h}$ after addition according to the Detection kit II (Roche). Cells that had incorporated BrdU were visualized and quantified using a Leica DMR microscope. For in ovo labeling, BrdU $(10 \mathrm{mM})$ containing fast green $(0.25 \mu \mathrm{L} / \mathrm{mL})$ in PBS was injected into chick embryos $1 \mathrm{~h}$ before sacrificing. Mouse embryos were dissected in DMEM plus 10\% FCS at 8.5 $\mathrm{dpc}$, leaving the extraembryonic membranes intact. BrdU (10 $\mathrm{mM}$ ) was immediately injected into the amniotic cavity, and the embryos were cultured for $1 \mathrm{~h}$. They were fixed overnight in $4 \%$ paraformaldehyde at $4^{\circ} \mathrm{C}$, dehydrated through a series of ethanol, and rehydrated. In the case of chick embryos, after fixation, dehydration, and rehydration, immunohistochemistry was carried out on 15- $\mu$ m paraffin sections (Fibrowax, BDH). After paraffin removal with HistoClear, the chick embryo sections were rehydrated, and both the chick sections and mouse embryos were processed to develop BrdU incorporation following the manufacturer's instructions (Roche).

Cells undergoing mitosis were identified by the presence of phospho-histone-3 (Prigent and Dimitrov 2003) in 50- $\mu \mathrm{m}$ vibratome sections obtained from mouse and chicken embryos. The 
sections were incubated overnight with PBT (PBS, 0.5\% Triton $\mathrm{X}-100)$ at $4^{\circ} \mathrm{C}$ and subsequently treated with $0.1 \% \mathrm{H}_{2} \mathrm{O}_{2}$ for $4 \mathrm{~h}$ at room temperature. After washing, they were blocked with $10 \%$ FCS and $1 \mathrm{mg} / \mathrm{mL}$ BSA in PBT for $3 \mathrm{~h}$ at $4^{\circ} \mathrm{C}$. Incubation with primary and secondary (biotinylated) antibodies was performed overnight at $4^{\circ} \mathrm{C}$. After washing, the sections were developed with the $\mathrm{ABC}$ kit (Pierce).

\section{Analysis of DNA content by flow cytometry}

Cells were detached from dishes with trypsin, fixed in $70 \%$ ethanol $\left(-20^{\circ} \mathrm{C}\right)$ for $1 \mathrm{~min}$, and treated with RNAse $(1 \mathrm{mg} / \mathrm{mL})$ for $15 \mathrm{~min}$ at $37^{\circ} \mathrm{C}$. After propidium iodide staining $(0.05 \mathrm{mg} /$ $\mathrm{mL}$ in PBS $15 \mathrm{~min}$ at room temperature in the dark), the cellular DNA content was evaluated in a FACS flow cytometer (BectonDickinson). For computer analysis, only signals from single cells were considered $(10,000$ cells/assay).

\section{Western blots and immunoprecipitation assays}

Cells were scraped off the plates after washing with cold PBS and lysed at $4^{\circ} \mathrm{C}$ in the following buffer: $20 \mathrm{mM}$ Tris- $\mathrm{HCl}$ at $\mathrm{pH}$ 7.4, $10 \mathrm{mM}$ EDTA, $100 \mathrm{mM} \mathrm{NaCl}, 1 \%$ Triton $\mathrm{X}-100,1 \mathrm{mM} \mathrm{NaF}$, $100 \mathrm{mM} \beta$-glycerophosphate, $1 \mathrm{mM}$ EGTA, $5 \mathrm{mM} \mathrm{NaPPi}, 5$ $\mu \mathrm{g} / \mathrm{mL}$ leupeptin, $1 \mathrm{mM}$ sodium o-vanadate, and $1 \mathrm{mM}$ PMSF. Proteins were separated by SDS-PAGE on $12 \%$ or $7.5 \%$ (for retinoblastoma protein), and transferred to PVDF membranes (Millipore) that were then blocked in TTBS (TBS plus $0.05 \%$ Tween-20) containing 5\% nonfat dried milk. The membranes were incubated for $2 \mathrm{~h}$ with the corresponding primary antibody at room temperature in blocking solution. After washing, they were incubated with peroxidase-conjugated anti-mouse or antirabbit immunoglobulin for $1 \mathrm{~h}$ at room temperature (1:3000). Antibody binding was visualized by ECL (Amersham Biosciences).

For immunoprecipitation assays to detect levels of p21 and p27, the cells were lysed and the proteins purified as above. Equal amounts of total protein $(400 \mu \mathrm{g})$ were incubated with 1 $\mu \mathrm{g}$ of the appropriate antibody (p21/Cip1 or p27/Kip1) and protein A-agarose beads (Sigma) for $3 \mathrm{~h}$ at $4^{\circ} \mathrm{C}$, and the beads were washed twice with lysis buffer, centrifuged, resolved by SDSPAGE, and subjected to immunoblot analysis as described above.

\section{RT-PCR analysis and primer sequence}

Poly $(\mathrm{A})^{+}$mRNA was isolated from MDCK cells using the Microfast Track isolation kit (Invitrogen) and treated with DNAse I before cDNA synthesis. Reverse transcription was carried out as described (Sefton et al. 1998), and PCR to amplify coding fragments for canine Cyclins D1 and D2 was performed over 35 cycles at an annealing temperature of $55^{\circ} \mathrm{C}$ using primers as follows. For Cyclin D1, primers derived from the mouse sequence were used: forward, 5'-CTGCGAAGTGGAGACCAT CCG-3'; and reverse, 5'-GTCCGGGTCACACTTGATGAC-3' (mouse-specific primers). For Cyclin D2, degenerate primers were used: forward, 5'-GAA/GGAA/GC/AGITAT/CT/CTIC CICAA/GTG-3'; and reverse, 5'-GAA/GTACATIGCA/GAAT/ CTTA/GAAA/GTC-3'. The amplified fragments were subcloned in pGEMT-easy and sequenced. After sequencing, dogspecific primers were designed and after a similar amplification protocol, the fragment was subcloned, sequenced, and used for Northern blot analysis.

\section{Northern blots}

Total RNA was isolated as described by Chomczynski and Sacchi (1987). For each assay, $20 \mu \mathrm{g}$ of denatured RNA was used per lane. The coding fragments for canine Cyclins D1 and D2 obtained by RT-PCR as described above were labeled using the Rediprime II kit (Amersham Biosciences). A human GAPDH (glyceraldehyde-3-phosphate dehydrogenase) probe was used as a control for the quantity of RNA.

\section{Transient transfections and promoter analysis}

To analyze the Cyclin D2 promoter, mouse epidermal keratinocyte MCA3D cells were cotransfected with $40 \mathrm{ng}$ of Renilla vector and $400 \mathrm{ng}$ of pGL3 vector (Promega) containing the $C y$ clin D2 promoter fused to the Luciferase reporter gene together with $25 \mathrm{ng}$ of human SNAIl or mouse Snail complete coding sequences in pZeo (Invitrogen) and pcDNA3 (Invitrogen) vectors, respectively. Control transfections were performed with the empty plasmids (Mock). Transfections were carried out using Lipofectamine (Life Technologies). Luciferase and Renilla activities were assayed using the dual-luciferase reporter system kit (Promega), and the activity normalized to that of the promoter cotransfected with the control vectors. Human D2-Luc (1624 base pairs) and the deletions -1303 D2-Luc and -444 D2Luc were kindly provided by Brad H. Nelson (Martino et al. 2001). The D2-Luc (-1624) was used to delete and mutate the two E-boxes present in the human Cyclin D2 promoter with a Quickchange Site Directed Mutagenesis Kit (Stratagene). The core sequence 5'-GCACGTGC-3' contained in the two E-boxes of the human Cyclin D2 promoter was independently mutated to $5^{\prime}$-TTACGTGC-3'. These two point mutations (GC to TT) abolish the E-box and were shown to derepress the proximal mouse E-cadherin promoter (Cano et al. 2000).

\section{In situ hybridization}

Whole-mount in situ hybridization was carried out in chick and mouse embryos at several stages of development as described (Nieto et al. 1996). Digoxigenin-labeled probes were synthesized from the full-length cDNA of mouse Snail and chick Slug. Probes for the mouse Cyclins D1 and D2 were synthesized from cDNAs obtained from the mouse epithelial cell line NMuMG and amplified by RT-PCR with the primers and conditions described above. Following hybridization, the embryos were incubated with alkaline phosphatase-conjugated anti-digoxigenin antibody. The alkaline phosphatase activity was detected by incubation with NBT/BCIP substrates (Roche). After hybridization, embryos were fixed in $4 \%$ paraformaldehyde in PBS, washed, and photographed in whole mount under a Leica M10 dissecting scope. Subsequently, mouse embryos were embedded in paraffin (Fibrowax), sectioned at $15 \mu \mathrm{m}$, and photographed using a Leica DMR microscope.

\section{Cell death analysis in cell lines and embryos}

Cells were grown on coverslips in 6-cm cell culture dishes and stained with propidium iodide $(0.05 \mathrm{mg} / \mathrm{mL})$ in PBS for $15 \mathrm{~min}$ at room temperature in the dark. Only cells with altered membrane permeability were stained and could be visualized using a Leica DMR microscope.

For the analysis of apoptosis in embryos, DNA fragmentation was detected using the TUNEL in situ cell death detection kit (Roche) or by staining with Nile Blue Sulphate (NBS; Sigma) that marks dying cells. For TUNEL detection, whole embryos were fixed in $4 \%$ paraformaldehyde in $\mathrm{PBT}$ at $4^{\circ} \mathrm{C}$, dehydrated and treated for $2 \mathrm{~h}$ at room temperature in $100 \%$ methanol plus $1 \% \mathrm{H}_{2} \mathrm{O}_{2}$, and washed several times in methanol. After rehydration the embryos were digested with proteinase $\mathrm{K}(10 \mu \mathrm{g} / \mathrm{mL}$ for $3 \mathrm{~min}$ ) at room temperature, washed, and fixed for $30 \mathrm{~min}$ in 
4\% paraformaldehyde. After several washes, they were treated with the reaction mix for $2 \mathrm{~h}$ at $37^{\circ} \mathrm{C}$, washed, blocked for $2 \mathrm{~h}$ with blocking solution (KTBT $0.1 \%$ Triton X-100, 15\% FCS, $0.7 \%$ blocking powder from Roche), and incubated with the POD-converter $\left(1 \mathrm{~h}\right.$ at $\left.37^{\circ} \mathrm{C}\right)$. Embryos were developed in the dark with DAB (3,3'-Diaminobenzidine, Sigma) containing $0.03 \% \mathrm{H}_{2} \mathrm{O}_{2}$. After washing, embryos were photographed and embedded in $0.5 \%$ gelatin (Sigma) prior to being sectioned at 40 $\mu \mathrm{m}$ on a vibratome. NBS staining was carried out on whole embryos immediately after dissection. The embryos were incubated in NBS $(20 \mu \mathrm{g} / \mathrm{mL}$ in PBS) containing $0.1 \%$ Tween 20 for 30 min at room temperature, briefly washed in PBS, and immediately photographed in $4 \%$ PFA.

\section{Analysis of caspase-3 and caspase-8 activities}

Cells attached to the dish and those in the supernatant were collected and lysed at $4^{\circ} \mathrm{C}$ in $5 \mathrm{mM}$ Tris- $\mathrm{HCl}$ at $\mathrm{pH} 8.0,20 \mathrm{mM}$ EDTA, and 0.5\% Triton X-100. Ac-DEVD-AMC and Ac-IETDAFC were used as substrates to measure the enzymatic activities of caspase- 3 and caspase-8, respectively (Herrera et al. 2001). Analyses were performed in a Luminescence Spectrophotometer (Perkin-Elmer LS-50). A unit of caspase activity was defined as the amount of active enzyme necessary to produce an increase of 1 arbitrary luminescence unit in $2 \mathrm{~h}$. The protein concentration of the cell lysates was determined with the Bio-Rad assay kit, and the results are presented as units of caspase activity per $\mu \mathrm{g}$ of protein.

\section{PI3-kinase activity}

After solubilization of cells in lysis buffer $(10 \mathrm{mM}$ Tris- $\mathrm{HCl}, 5$ mM EDTA, $50 \mathrm{mM} \mathrm{NaCl}, 30 \mathrm{mM} \mathrm{NaPPi}, 50 \mathrm{mM} \mathrm{NaF}, 100 \mu \mathrm{M}$ sodium o-vanadate, $1 \%$ Triton $\mathrm{X}-100$ at $\mathrm{pH} 7.6)$ containing leupeptin $(10 \mu \mathrm{g} / \mathrm{mL})$, aprotinin $(10 \mu \mathrm{g} / \mathrm{mL})$ and $1 \mathrm{mM} \mathrm{PMSF}$, lysates were clarified by centrifugation, and the proteins were immunoprecipitated with a monoclonal anti-Tyr-Phosphate antibody (Py72). Immunoprecipitates were used to analyze PI 3-kinase activity by in vitro phosphorylation of phosphatidylinositol as described (Valdés et al. 2004).

\section{Chick embryo electroporation}

In ovo electroporation was essentially carried out as described (Del Barrio and Nieto 2002) with the following modifications: pCX-EGFP construct (1 mg/mL; Ikawa et al. 1995) was co-electroporated with pCX-Slug $(1.5 \mathrm{mg} / \mathrm{mL})$ containing the fulllength chick Slug cDNA or with the empty pCX vector as a control. The DNAs were injected into stage 8 chick hindbrains in ovo and electroporated using two $50-\mathrm{msec} 10 \mathrm{~V}$ pulses. The embryos were allowed to develop for a further 14-16 h. In all the experiments the control side was to the left. Embryos were photographed in ovo to record GFP expression and processed for apoptosis analysis.

\section{Acknowledgments}

We thank members of the Nieto lab for helpful discussions throughout the completion of this work, B. Nelson for Cyclin D2 constructs, J. Miyazaki and M. Okabe for providing the pCX-EGFP plasmid, A. Vázquez for help with the flow cytometry analysis, and M. Sefton for critical reading of the manuscript and editorial assistance. This work was supported by grants from the Spanish Ministry of Science and Technology (DGICYT-BMC2002-0383 to M.A.N.), the Ministry of Health
(FIS-01/985 to M.A.N. and FIS-01/0797 to I.F.), and the Comunidad Autónoma de Madrid (CAM 08.1/0044/2000 and 08.1/ 0049.1/2003 to M.A.N. and CAM 08.1/0078/2000 and 08.1/ 0003.1/2003 to I.F.). A.V.M. was supported by Advancell S.L. and the I3P Program (European Social Fund/Spanish Ministry of Science and Technology), and O.H.O. was the recipient of a predoctoral fellowship form the Spanish Ministry of Education and Culture.

The publication costs of this article were defrayed in part by payment of page charges. This article must therefore be hereby marked "advertisement" in accordance with 18 USC section 1734 solely to indicate this fact.

\section{References}

Aybar, M., Nieto, M.A., and Mayor, R. 2003. Snail precedes Slug in the genetic cascade required for the specification and migration of the Xenopus neural crest. Development 130: 483 494.

Batlle, E., Sancho, E., Franci, C., Dominguez, D., Monfar, M., Baulida, J., and Garcia De Herreros, A. 2000. The transcription factor Snail is a repressor of E-cadherin gene expression in epithelial tumor cells. Nat. Cell Biol. 2: 84-89.

Blanco, M.J., Moreno-Bueno, G., Sarrio, D., Locascio, A., Cano, A., Palacios, J., and Nieto, M.A. 2002. Correlation of Snail expression with histological grade and lymph node status in breast carcinomas. Oncogene 21: 3241-3246.

Bonneton, C., Sibarita, J.-B., and Thiery, J.P. 1999. Relationship between cell migration and cell cycle during the initiation of epithelial to fibroblastoid transition. Cell Mot. Cytosk. 43: 288-295.

Bouchard, C., Dittrich, O., Kiermaier, A., Dohmann, K., Menkel, A., Eilers, M., and Luscher, B. 1999. Direct induction of cyclinD2 by Myc contributes to cell cycle progression and sequestration of p27. EMBO J. 18: 5321-5333.

Burstyn-Cohen, T. and Kalcheim, C. 2002. Association between cell cycle and neural crest delamination through specific regulation of G1/S transition. Dev. Cell 3: 383-395.

Cano, A., Pérez, M.A., Rodrigo, I., Locascio, A., Blanco, M.J., Del Barrio, M.G., Portillo, F., and Nieto, M.A. 2000. The transcription factor Snail controls epithelial-mesenchymal transitions by repressing E-cadherin expression. Nat. Cell Biol. 2: 76-83.

Carver, E.A., Jiang, R., Lan, Y., Oram, K.F., and Gridley, T. 2001. The mouse Snail gene encodes a key regulator of the epithelial-mesenchymal transition. Mol. Cell. Biol. 21: 8184-8188.

Cheng, C.W., Wu, P.E., Yu, J.C., Huang, C.S., Yue, C.T., Wu, C.W., and Shen, C.Y. 2001. Mechanisms of inactivation of E-cadherin in breast carcinoma: Modification of the two-hit hypothesis of tumor suppressor gene. Oncogene 20: 3814 3823.

Chomczynski, P. and Sacchi, N. 1987. Single step method of RNA isolation by acid guanidinium thiocyanate-phenolchloroform extraction. Anal. Biochem. 162: 156-159.

Cui, W., Fowlis, D.J., Bryson, S., Duffie, E., Ireland, H., Balmain, A., and Akhurst, R.J. 1996. TGF- $\beta$ inhibits the formation of benign skin tumors, but enhances progression to invasive spindle carcinomas in transgenic mice. Cell 86: 531-542.

Del Barrio, M.G. and Nieto, M.A. 2002. Overexpression of Snail family members highlights their ability to promote chick neural crest formation. Development 129: 1583-1593.

Dickinson, M.E., Selleck, M.A., McMahon, A.P., and BronnerFraser, M. 1995. Dorsalization of the neural tube by the nonneural ectoderm. Development 121: 2099-2106.

Ellies, D.L., Church, V., Francis-West, P., and Lumsden, A. 2000. The WNT antagonist cSFRP2 modulates programmed 
cell death in the developing hindbrain. Development 127: 5285-5295.

Ellies, D.L., Tucker, A.S., and Lumsden, A. 2002. Apoptosis of premigratory neural crest cells in rhombomeres 3 and 5 : Consequences for patterning of the branchial region. Dev. Biol. 251: 118-128.

Foe, V.E. 1989. Mitotic domains reveals early commitment of cells in Drosophila embryos. Development 107: 1-22.

Gotzmann, J., Huber, H., Thallinger, C., Wolschek, M., Jansen, B., Schulte-Hermann, R., Beug, H., and Mikulits, W. 2002. Hepatocytes convert to a fibroblastoid phenotype through the cooperation of TGF- $\beta 1$ and Ha-Ras: Steps towards invasiveness. J. Cell Sci. 115: 1189-1202.

Graham, A., Francis-West, P., Brickell, P., and Lumsden, A. 1994. The signalling molecule BMP4 mediates apoptosis in the rhombencephalic neural crest. Nature 372: 684-686.

Graham, A., Koentges, G., and Lumsden, A. 1996. Neural crest apoptosis and the establishment of the craniofacial pattern: An honorable death. Mol. Cell. Neurosci. 8: 76-83.

Guaita, S., Puig, I., Franci, C., Garrido, M., Domínguez, D., Batlle, E., Sancho, E., Dedhar, S., De Herreros, A.G., and Baulida, J. 2002. Snail induction of epithelial to mesenchymal transition in tumor cells is accompanied by MUC1 repression and ZEB1 expression. J. Biol. Chem. 277: 3920939216.

Hamburger, V. and Hamilton, H. 1951. A series of normal stages in the development of the chick embryo. J. Morphol. 88: 4992.

Herrera, B., Fernández, M., Álvarez, A.M., Roncero, C., Benito, M., Gil, J., and Fabregat, I. 2001. Activation of caspases occurs downstream from radical oxygen species production, $\mathrm{Bcl}-\mathrm{x}_{\mathrm{L}}$ down-regulation, and early cytochrome c release in apoptosis induced by transforming growth factor $\beta$ in rat fetal hepatocytes. Hepatology 34: 548-556.

Ikawa, M., Kominami, K., Yoshimura, Y., Tanaka, K., Nishimune, Y., and Okabe, M. 1995. A rapid and non-invasive selection of transgenic embryos before implantation using green fluorescent protein (GFP). FEBS Lett. 375: 125-128.

Ikenouchi, J., Matsuda, M., Furuse, M., and Tsukita, S. 2003. Regulation of tight junctions during epithelium-mesenchyme transition: direct repression of the gen expression of claudins/occludin by Snail. J. Cell Sci. 116: 1959-1967.

Inoue, A., Seidel, M.G., Wu, W., Kamizono, S., Ferrando, A.A., Bronson, R.T., Iwasaki, H., Akashi, K., Morimoto, A., Hitzler, J.K., et al. 2002. Slug, a highly conserved zinc finger transcriptional repressor, protects hematopoietic progenitor cells from radiation-induced apoptosis in vivo. Cancer Cell 2: $279-288$.

Inukai, T., Inoue, A., Kurosawa, H., Goi, K., Shinjyo, T., Ozawa, K., Mao, M., Inaba, T., and Look, A.T. 1999. Slug, a ces-1related zinc finger transcription factor gene with antiapoptotic activity is a downstream target of the E2A-HLF oncoprotein. Mol. Cell 4: 343-352.

Iwasaki, T., Shinkai, K., Mukai, M., Yoshioka, K., Fujii, Y., Nakahara, K., Matsuda, H., and Akedo, H. 1995. Cell-cycledependent invasion in vitro by rat ascites hepatoma cells. Int. J. Cancer 63: 282-287.

Jung, A., Schrauder, M., Oswald, U., Knoll, C., Sellberg, P., Palmqvist, R., Niedobitek, G., Brabletz, T., and Kirchner, T. 2001. The invasion front of human colorectal adenocarcinomas shows co-localization of nuclear $\beta$-catenin, cyclin $\mathrm{D}_{1}$, and $\mathrm{p} 16^{\mathrm{INK} 4 \mathrm{~A}}$ and is a region of low proliferation. Am. I. Pathol. 159: 1613-1617.

Lehmann, K., Janda, E., Pierreux, C.E., Rytomaa, M., Schulze, A., McMahon, M., Hill, C.S., Beug, H., and Downward, J. 2000. Raf induces TGF $\beta$ production while blocking its apo- ptotic but not invasive responses: A mechanism leading to increased malignancy in epithelial cells. Genes \& Dev. 14: 2610-2622.

Liem Jr., K.F., Tremml, G., Roelink, H., and Jessell, T. 1995. Dorsal differentiation of neural plate cells induced by BMPmediated signals from epidermal ectoderm. Cell 82: 969-979.

Locascio, A., Manzanares, M., Blanco, M.J., and Nieto, M.A. 2002. Modularity and reshuffling of Snail and Slug expression during vertebrate evolution. Proc. Natl. Acad. Sci. 99: 16841-16846.

Manzanares, M., Locascio, A., and Nieto, M.A. 2001. The increasing complexity of the Snail superfamily in metazoan evolution. Trends Genet. 17: 178-181.

Martino, A., Holmes IV, J.H., Lord, J.D., Moon, J.J., and Nelson, B.H. 2001. Stat5 and Sp1 regulate transcription of the cyclin D2 gene in response to IL-2. J. Immunol. 166: 1723-1729.

Mauhin, V., Lutz, Y., Dennefeld, C., and Alberga, A. 1993. Definition of the DNA-binding site repertoire for the Drososphila transcription factor SNAIL. Nucleic Acids Res. 21: 3951-3957.

Metzstein, M.M. and Horwitz, H.R. 1999. The C. elegans cell death specification gene ces-1 encodes a Snail family zinc finger protein. Mol. Cell 4: 309-319.

Nieto, M.A. 2002. The Snail superfamily of zinc finger transcription factors. Nat. Rev. Mol. Cell Biol. 3: 155-166.

Nieto, M.A., Bennet, M.F., Sargent, M.G., and Wilkinson, D.G. 1992. Cloning and developmental expression of Sna, a murine homologue of the Drosophila snail gene. Development 116: $227-237$.

Nieto, M.A., Sargent, M.G., Wilkinson, D.G., and Cooke, J. 1994. Control of cell behavior during vertebrate development by Slug, a zinc finger gene. Science 264: 835-839.

Nieto, M.A., Patel, K., and Wilkinson, D.G. 1996. In situ hybridisation analysis of chick embryos in whole mount and tissue sections. Meth. Cell Biol. 51: 220-235.

Ortega, S., Malumbres, M., and Barbacid, M. 2002. Cyclin Ddependent kinases, INK4 inhibitors and cancer. Biochim. Biophys. Acta 1602: 73-87.

Peinado, H., Quintanilla, M., and Cano, A. 2003. Transforming growth factor $\beta 1$ induces Snail transcription factor in epithelial cell lines. J. Biol. Chem. 278: 21113-21123.

Pérez-Losada, J., Sánchez-Martín, M., Pérez-Caro, M., PérezMancera, P.A., and Sánchez-García, I. 2003. The radioresistance biological function of the SCF/kit signaling pathway is mediated by the zinc-finger transcription factor Slug. Oncogene 22: 4205-4211.

Piedra, M.E. and Ros, M.A. 2002. BMP signaling positively regulates Nodal expression during left right specification in the chick embryo. Development 129: 3431-3440.

Prigent, C. and Dimitrov, S. 2003. Phosphorylation of serine 10 in histone H3, what for? J. Cell Sci. 116: 3677-3685.

Ramljak, D., Coticchia, C.M., Nishanian, T.G., Saji, M., Ringel, M.D., Conzen, S.D., and Dickson, R.B. 2003. Epidermal growth factor inhibition of c-Myc-mediated apoptosis through Akt and Erk involve Bcl- $\mathrm{x}_{\mathrm{L}}$ upregulation in mammary epithelial cells. Exp. Cell Res. 287: 397-410.

Ratner, S. 1992. Lymphocyte migration through extracellular matrix. Inv. Metast. 12: 82-100.

Romano, L. and Runyan, R.B. 2000. Slug is and essential target of TGF 32 signaling in the developing chicken heart. Dev. Biol. 223: 91-102.

Rosivatz, E., Becker, I., Specht, K., Fricke, E., Luber, B., Busch, R., Hofler, H., and Becker, K.F. 2002. Differential expression of the epithelial-mesenchymal transition regulators snail, SIP1 and twist in gastric cancer. Am. I. Pathol. 161: 1881- 
1891.

Sefton, M., Sánchez, S., and Nieto, M.A. 1998. Conserved and divergent roles for members of the Snail family of transcription factors in the chick and mouse embryo. Development 125: 3111-3121.

Siegel, P.M. and Massagué, J. 2003. Cytostatic and apoptotic actions of TGF- $\beta$ in homesotasis and cancer. Nat. Rev. Cancer 3: 807-820.

Smith, D.E., Franco del Amo, F., and Gridley, T. 1992. Isolation of Sna, a mouse gene homologous to the Drosophila genes snail and escargot: Its expression pattern suggests multiple roles during postimplantation development. Development 116: 1033-1039.

Spagnoli, F.M., Cicchini, C., Tripodi, M., and Weiss, M.C. 2000. Inhibition of $\mathrm{MMH}$ (Met murine hepatocyte) cell differentiation by TGF- $\beta$ is abrogated by pretreatment with the inheritable differentiation factor FGF1. J. Cell Sci. 113: 36393647.

Sugimachi, K., Tanaka, S., Kameyama, T., Taguchi, K., Aishima, S., Shimada, M., Sugimachi, K., and Tsuneyoshi, M. 2003. Transcriptional repressor Snail and progression of human hepatocellular carcinoma. Clin. Cancer Res. 9: 2657-2664.

Thellmann, M., Hatholz, J., and Conradt, B. 2003. The Snail-like Ces-1 protein of C.elegans can block the expression of the BH3-only cell-death activator gene egl-1 by antagonizing the function of basic HLH proteins. Development 130: $4057-$ 4071.

Thiery, J.P. 2002. Epithelial-mesenchymal transitions in tumor progression. Nat. Rev. Cancer 2: 442-454.

Trainor, P.A., Sobieszczuk, D., Wilkinson, D., and Krumlauf, R. 2002. Signalling between the hindbrain and paraxial tissues dictates neural crest migration pathways. Development 129: 433-442.

Valdés, F., Álvarez, A.M., Locascio, A., Vega, S., Herrera, B., Fernández, M., Benito, M., Nieto, M.A., and Fabregat, I. 2002. The epithelial mesenchymal transition confers resistance to the apoptotic effects of TGF- $\beta$ in fetal rat hepatocytes. Mol. Cancer Res. 1: 68-78.

Valdés, F., Murillo, M., Valverde, A.M., Herrera, B., Sánchez, A., Benito, M., Fernández, M., and Fabregat, I. 2004. Transforming growth factor- $\beta$ (TGF- $\beta$ ) activates both pro-apoptotic and survival signals in fetal rat hepatocytes. Exp. Cell Res. 292: 209-218.

Yáñez-Mo, M., Lara-Pezzi, L., Segas, R., Ramírez-Huesca, M., Dominguez-Jiménez, C., Jiménez-Haffernan, J.A., Aguilera, A., Sánchez-Tomero, J.A., Bajo, M.A., Alvarez, V., et al. 2003. Peritoneal dialysis and epithelial-to-mesenchymal transition of mesothelial cells. N. Engl. J. Med. 348: 403-413.

Yang, W., Klos, K.S., Zhou, X., Yao, J., Yang, Y., Smith, T.L., Shi, D., and Yu, D. 2003. ErbB2 overexpression in human breast carcinoma is correlated with p21Cip1 up-regulation and tyrosine-15 hyperphosphorylation of p34Cdc2: Poor responsiveness to chemotherapy with cyclophoshamide methotrexate, and 5-fluorouracil is associated with Erb2 overexpression and with p21Cip1 overexpression. Cancer 98: $1123-1130$.

Yokohama, K., Kamata, N., Fujimoto, R., Tsutsumi, S., Tomonari, M., Taki, M., Hosokawa, H., and Nagayama, M. 2003. Increased invasion and matrix metalloproteinase- 2 expression by Snail-induced mesenchymal transition in squamous cell carcinomas. Int. J. Oncol. 22: 891-898. 


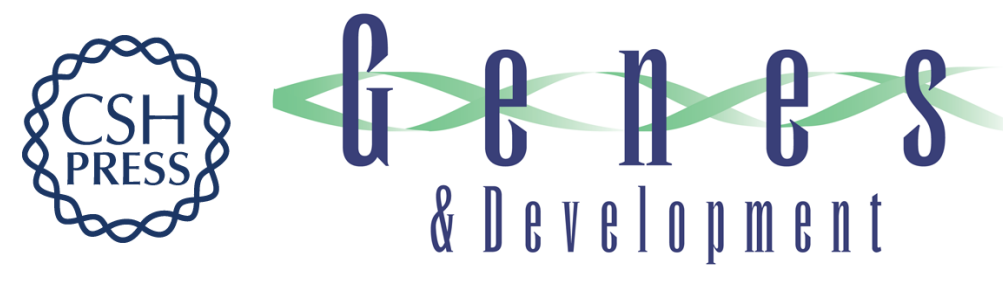

\section{Snail blocks the cell cycle and confers resistance to cell death}

Sonia Vega, Aixa V. Morales, Oscar H. Ocaña, et al.

Genes Dev. 2004, 18:

Access the most recent version at doi:10.1101/gad.294104

References This article cites 59 articles, 23 of which can be accessed free at: http://genesdev.cshlp.org/content/18/10/1131.full.html\#ref-list-1

License

Email Alerting Receive free email alerts when new articles cite this article - sign up in the box at the top Service right corner of the article or click here.

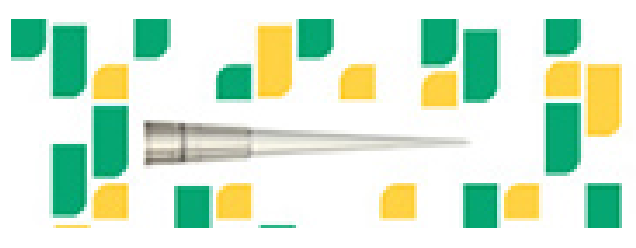

Focused on your science. 